\title{
MODELS OF TRANSITION TO ADULTHOOD OF DIFFERENT RUSSIAN GENERATIONS
}

\author{
EKATERINA MITROFANOVA
}

\begin{abstract}
This paper is devoted to the analysis of the starting events marking the transition to adulthood, such as completion of education (vocational and higher), first employment, first separation from parents, first partnership, first marriage, and first childbirth.
\end{abstract}

The dataset of the research is the Russian part of the Generations and Gender Survey (GGS). We prepared a harmonised dataset of the three waves (2004, 2007, and 2011), which included 5,451 respondents born between 1930 and 1986. We used two complementary approaches to study the transition to adulthood: the analysis of the starting sociodemographic events separately and the analysis of all of them as a part of one process. We depicted the results of the analysis on a demographic Lexis grid, which allowed us to observe the influence of the historical and institutional context on people's behaviour.

The research revealed three models of transition to adulthood in Russia: "Soviet" (generations of 1940-49, 1950-59, and 1960-69), "Transitional" (generations of 1930-39 and 1970-79), and "Post-Soviet" (the generation of 1980-86). Our classification is similar to the idea of the convergence of the patterns of the starting events' occurrence which assumes a change from the "traditional" model ("early, contracted and simple") to the "modern" model ("late, protracted and complex"). The similarity of the changes in Russian and European models confirms the stadiality of the modernisation process. The study also confirms the assumption of the Life Course Approach about the individualisation of the life course.

Key words: Russia, transition to adulthood, generations, starting life-course events, demographic events, socioeconomic events, demographic transition, marriage, childbearing, partnership, employment, education, leaving parents.

\section{INTRODUCTION}

For many millennia the survival of human societies was threatened by constant risks, making the main focus of a society's adults the provision of livelihoods and the reproduction of the population. Because the average life expectancy was only 20-30 years for much of that time, it was necessary to use one's available time as efficiently as possible and begin to participate in labor activity and reproduction of offspring as early as possible.

Standard life schedules did not give much time to prepare for adulthood. In most traditional societies there existed short, well-regulated rites of passage into adult status. These were formal, mandatory and achievable by almost all members of society. They played an important role, since they publicly and explicitly marked the moment at which individuals made the transition from the group of children or adolescents to the group of adults. Also, these rituals reduced the tension and uncertainty arising from changes in both an individual's social status and the organization of his life as he transitioned to a new age group (Remschmidt 1994). Initiation ceremonies ensured the continuity of generations and the invariability of the social structure which had been recreating the past of parents into the future of their children (Mead 1988).

\footnotetext{
EKATERINA Mitrofanova (mitrofanovy@yandex.ru), NATIONAL RESEARCH UNIVERSITY HighER SCHOOL OF Economics, The Russian Presidential Academy of National Economy and Public Administration, Russia.

THIS ARTICLE IS THE PRODUCT OF A RESEARCH PROJECT IMPLEMENTED AS PART OF THE BASIC RESEARCH PROGRAMME AT THE NATIONAL RESEARCH UNIVERSITY HighER SCHOOL OF ECONOMICS (HSE) 2019.
}

THE ORIGINAL ARTICLE IN RUSSIAN WAS PUBLISHED IN DEMOGRAPHIC REVIEW 2019. 6(4): 53-82. DOI: 10.17323/DEMREVIEW.V6I4.10427 
Over the past one and a half to two centuries, the life of society and the individual has undergone serious quantitative and qualitative transformations. Lives in developed countries have become not only two to three times longer, but also significantly healthier and full of amenities and technologies. In a postindustrial society, the basic needs of most people are satisfied, so that the task of survival and the need for early and universal childbearing associated with it are no longer as acute as before. As a result, the focus of the members of developed countries has shifted from survival to the improvement of the quality of life, individual development and investment in human capital.

Studies of modern Western societies show that the doubling of life expectancy leads to "age inflation" (Shoven, Goda 2011) and shifts the age boundaries of different stages of life. It is no longer necessary to grow up fast, and due to the many complications of the socio-economic and political structure of society, as well as to the emergence of professions that require a long preparation, there is a marked trend towards a slowing down and lengthening of the transition to adulthood.

The process of preparing an individual for adulthood is becoming so complex and multidimensional that it no longer fits into a system of simple rituals and rigid schemes. Generalization of the experience of developed countries (Billari, Liefbroer 2010; Arnett 2012) shows an erosion of age boundaries and the criteria of adulthood, as well as a replacement of external regulation of the transition to adult life with an internal one, one which is more varied, individual and reflective. That is, both quantitative and qualitative aspects of the transition to adulthood are changing.

At the same time, we still know little about how the transition to adulthood in Russia is changing, since there are few large comprehensive studies devoted to the study of this issue. Yet both demographers and sociologists report that, since the collapse of the USSR, the onset of certain demographic and socioeconomic events in people's lives has begun to change (Arkhangelsky 2013; Blum, Lefebvre et al. 2010; Gimpelson, Zudina 2017; Zakharov 2009; Zdravomyslova, Shurygina 2001; Konstantinovsky 2008; Magun, Engovatov 2006; Mills 2004; Potârcă, Mills, Lesnard 2013).

The onset of starting events in the aggregate (the holistic approach), rather than separately (the event approach), is rarely studied based on Russian data, and most often suffers from limitations on the number of events included and the angles of analysis. For example, a 2010 work (Blum, Sebiy, Zakharov 2010) compares the transition to adulthood of generations of Russians and French, but pays no attention to gender and other important types of differentiation. In another study (Zakharov 2009), only the transition to adulthood of women was studied. In another publication, both sexes are considered, and the case of Russia is taken into account, but it is not analyzed in detail (Zsolt, Murinkó, Settersten 2014).

In this study, we take into account world experience in the study of the transition to adulthood, as well as empirical evidence of the transformation of demographic and socioeconomic behavior in Russia. The empirical analysis presented in the work makes it possible to get a comprehensive picture of the transition to adulthood in Russia and to compare the observed trends with examples of European countries. 


\section{THE THEORETICAL FRAMEWORK}

Transition to adulthood as a process, as a specific stage of life, is a relatively new phenomenon for humanity, and has been studied by science for only about a hundred years. A variety of disciplines - philosophy, psychology, sociology, demography, anthropology and other sciences - have shown interest in this stage of life, each with its own approach, but so far no unified concept of transition to adulthood and comprehensive methodology for analyzing this process have been proposed.

One can give the following generalized definition of transition to adulthood: it is the complex process of a person's transformation and acquisition of experience and statuses that allows him or her to take an independent position in society. Transition to adulthood is a multicomponent and multi-level process. It includes chronological, biological, legal, psycho-emotional, social and demographic components and proceeds on macro, meso and micro levels.

At the macro level, transition to adulthood is a process thanks to which one generation succeeds another. It embodies adaptive social practices, normative models of behavior and normative scenarios which constitute the socially and gender-differentiated sequences of life path events.

At the meso level, transition to adulthood is a process of physical, economic, and psychological separation of children from their parents, i.e., of children gaining independence.

At the micro level, transition to adulthood is a process by which an individual integrates into an existing social structure by internalizing norms existing in society regarding his or her own preferences.

There is still no consensus in the scientific community about how and what components of transition to adulthood need to be analyzed in order to get the most complete and objective picture of this process. Psychologists mainly use qualitative methods of analysis and study the attitude of individuals to the process of becoming adults, as well as a set of personal competencies that mark transition to adulthood (Arnett 2012). Demographers and sociologists most often study the factual layer - i.e. objective, observable events marking transition to adulthood. Such events usually include the following: completion of education, first job, first separation from parents, first partnership (cohabitation without registration of a relationship), first marriage, birth of a first child (Billari et al. 2005; Billari, Liefbroer 2010; Buchmann 1989; Liefbroer 1999).

The conceptual framework of an interdisciplinary study of the organization of people's lives is outlined by the the life course approach (LCA), which posits that modern life paths have ceased to be "standard", institutionalized, the same for everyone, and have become individualized or "customizable" (choice biography) (Giddens 1994; Heinz, Marshall 2003; Huinink 2013). LCA pays special attention to the study of the transition to adulthood, since this stage of life is marked by the highest concentration of significant events that change a person's social status and organization of life (Billari, Liefbroer 2007; Rindfuss 1991).

Another theoretical approach that systematizes knowledge about the onset of biographical events, including starting events, is the theory of demographic transition (TDT). TDT mainly studies the onset of demographic events, but the combination of LCA and TDT provides a more comprehensive picture of transition to adulthood. Changes in transition to adulthood are closely 
associated with the demographic transition and represent an important part of the demographic modernization of society.

The theory of demographic transition suggests that there are several stages of demographic modernization. At the first stage, the quantitative indicators of the main demographic processes change: the balance of high mortality and high fertility is replaced by the balance of low mortality and low fertility (Lesthaeghe 1995). At the second stage of the demographic transition, changes take place in the organization of family life and the separation of sexual, reproductive and matrimonial behavior (Vishnevsky 1976: 158). This second phase is often called the "second demographic transition" (van de Kaa 1987).

The demographic transition in different countries begins at different historical times and proceeds at different speeds. Among European countries, signs of demographic modernization first appeared in Western Europe, and then in Eastern Europe (Frejka, Zakharov 2012; Puur et al. 2012a; Puur et al. 2012b). The main signs of the second demographic transition are: the postponement of marriage and childbirth; the growing popularity of partnerships and the declining popularity of marriages; a decrease in the total number of children and an increase in the number of children born outside of a registered marriage (Lesthaeghe, Neels 2002; Vishnevsky 2006; Zakharov 2008).

Combining the ideas of LCA and TDT, sociologists and demographers have formed three main hypotheses interpreting the changes that occur with the transition to adulthood: some researchers believe that there is convergence between countries (a similarity of the patterns of transition to adulthood); others, that there is a divergence (a growth of regional differences); and the third group believes that a general movement of the modernization process is occurring in different countries in a similar way but with different speed, and some countries deviate from the normative model due to the specific socio-cultural features.

The assumption of the divergence of patterns of transition to adulthood and of individual behaviors marking the transition to adulthood is supported by Hajnal's study describing and explaining the historical differences in West and East European marriages (Hajnal 1965), as well as by more modern works: classification of the patterns of transition to adulthood in European countries (Cavalli, Galland 1993); clustering of European countries depending on the types of family policy (Ejrnœs, Boje 2008); classification of social policy regimes in European countries (Esping-Andersen 1990; 2007); the relationship between the characteristics of the transition to adulthood and the limitations and opportunities created by social policy regimes, the functioning of the labor market and family structure (Vogel 2002). The main conclusion of these studies is as follows: the most rapid transformation of models of transition to adulthood is found in the western and northern countries of Europe with more liberal social norms regarding the organization of family life and a more gender-balanced family and social policy of the state, while the preservation of previous, more traditional norms and patterns of behavior is typical of the eastern and southern countries of Europe with more family-oriented and gender-asymmetric state policies.

Explanatory concepts involving the convergence of models of transition to adulthood do not reject cultural, national and regional differences, but argue that over time these differences are weakening and a general movement toward modernization of demographic and socio-economic behavior is occurring. The idea of convergence is supported by a study of F.C. Billari and 
A.C. Liefbroer (Billari, Liefbroer 2010), who examined the change in the following characteristics of the onset of starting events in European countries: age of events (timing), intensity or speed (tempo) and order of events' occurrence (sequencing). They described the "traditional" model of transition to adulthood as "early, contracted and simple" (events occurred early, with small intervals and in the same order for almost everybody), and the modern one as "late, protracted and complex". The results of this study coincide with the assumptions of the theory of the second demographic transition and show that the age of the onset of starting events, especially demographic ones, is increasing in modern societies. The age of the occurrence of socio-economic events is changing less, so the transition to adulthood begins at about the same age as before, but ends later due to the postponement of demographic events. As result, the transition to adulthood stretches out over time. The sequence of events is also changing: it is becoming more mosaic, individualized and less predictable.

The idea of a convergence of transition to adulthood models is supported by comparative studies of family formation in France, Romania and Russia (Potârcă et al. 2013); in Canada, the Netherlands and Russia (Mills 2004); by the study of transition to adulthood in Belarus (Lapeto, Tereshchenko, Shaverdo 2018) and a review of works on transition to adulthood in Europe (Buchmann, Kriesi 2011).

The third point of view occupies a middle position between the hypotheses of divergence and convergence. It posits that the general direction of changes in the patterns of transition to adulthood in most countries coincides, but some countries retain a number of specific regional features.

A study of girls' transition to adulthood in different countries of Europe (Zakharov 2009) showed differences not only in timing and sequencing of starting events occurrence, but also in what events people in different countries consider as indicators of adulthood (idea of divergence). In Eastern European countries, as well as in Portugal, France and Cyprus, a woman's acquisition of adult status is more associated with starting a family and motherhood (which is often combined with full employment). In Western and Northern European countries, respondents consider that in order to grow up it is important to find a job and leave the parental home. S.V. Zakharov agrees that, on the whole, there is a convergence of transition to adulthood models as a result of "a common to developed countries transition to a certain "new" schedule of human life" (Zakharov 2009). Meanwhile, he confirms that some countries preserve regional differences due to their historical and cultural backgrounds.

A. Puur and co-authors in their study (Puur et al. 2012a; Puur et al. 2012b) found confirmation of both the stadiality of changes in matrimonial behavior (convergence) and the presence of regional differentiation (divergence): the transition to the new marriage model in Eastern Europe began several decades later than in Western Europe. Among Western countries, East Germany and Estonia started the transition first (15-20 years later than Eastern countries), and then Bulgaria, Hungary, Lithuania, Russia, and Romania (20-25 years later). The authors revealed that the process of modernization of demographic behavior does indeed go through certain stages, but the cultural and historical norms in different countries can have a significant impact on the content and speed of the modernization process. 
Let us summarize the main ideas of all these approaches. Today, in a number of countries, regional characteristics in the transition to adulthood are still observed, but some signs of a demographic transition and the convergence of transition to adulthood models are found in all European countries, including Russia (Arkhangelsky 2013; Dolbik-Vorobey 2003; Zakharov 2007; Chernova 2012; Shabunova, Kalachikova 2015).

In this paper, we carry out two analytical tasks: diachronic (comparing different generations of Russians among themselves) and synchronous (comparing the most recent Russian generations with their European peers and the trends they demonstrate). We study whether the patterns of transition to adulthood of modern youth are following in the tracks set by Western European countries (the idea of convergence) or are the models of transition to adulthood inherited from the Soviet generations (the idea of divergence, preserving regional differences). Using the explanatory concepts presented, we assume that, in general, the transition to adulthood of young Russians is modernizing, but, depending on the individual characteristics of the respondents (gender, generation, educational level, etc.), the difference between Soviet and modern generations will be either weaker or stronger.

\section{DATA AND ANALYSIS METHODS}

In our study, we examine the biographies of Russians and operationalize transition to adulthood through the presence of the starting events marking this process. We divide the starting sociodemographic events into two groups: socioeconomic (completion of education, first job, first leaving the parental home) and demographic (first partnership, first marriage, birth of the first child).

As a database we took the results of the Russian part of the international program supported by the United Nations Economic Commission for Europe "Generations and Gender Survey" (GGS). The survey was conducted in Russia 2004, 2007 and 2011, using a uniform questionnaire for all countries. For the purposes of this study, we created a panel sample of respondents who participated in all three waves of the survey (5451 respondents). All biographies are taken as of 2011. The sample included representatives of generations born between 1930 and 1986. A generational step is a 10-year interval. The last generation is truncated due to the panel nature of the data: in 2004, the youngest respondents were those born in 1986.

The onset of starting events was studied using methods of descriptive statistics such as frequency analysis, contingency tables, and the calculation of median ages of events occurrence. To assess the significance of the differences revealed, the chi-square criterion was used for the onset of events and the Kruskal-Wallis test for independent events - to test differences in median ages.

We used two complementary approaches to study the transition to adulthood: the event approach (analysis of the onset of starting events separately) and the holistic approach (analysis of transition to adulthood as a cumulative process). The first approach, found in most studies of demographers and sociologists, gives a full idea of certain areas of life, for example, the marital or educational sphere. However, when studying transition to adulthood, we are dealing with a holistic process characterized by several events (in our case, six), which can occur on individual 
life paths in a variety of combinations. In order to determine with what event and at what age transition to adulthood begins, it is necessary to sort all the starting events chronologically and to determine which of them was the first and at what age it occurred. The same goes for the second, third, and so on, right up to the last event that occurred. Thus, the event and holistic approaches differ methodologically: in the first case, we compare events of the same type, and in the second, we depersonalize the events, leaving only their order numbers and the ages at which they occurred.

The holistic approach is very informative in the analysis of transition to adulthood, as it takes into account the order of events in an individual biography. But this approach is very sensitive to the set of events that researchers define as marking adulthood. Thus, our previous studies showed that a partnership was not a common and approved starting event in the USSR (Artamonova, Mitrofanova 2014; Artamonova, Mitrofanova 2018), so it would be incorrect to include it in the normative set of adult markers for all generations.

Based on the foregoing, the methodological design of this study is as follows:

1. Event analysis: analysis of the facts and ages of the onset of each of the six starting events.

2. Holistic analysis: analysis of the facts and ages of the onset of events in their chronological sequence, highlighting of the first and last events in the chain of starting events. Partnership is excluded from the normative set of events as not typical for the Soviet era.

To visualize the results of the analysis, an instrument well known to demographers, the Lexis grid, was used. Its advantage lies in the possibility of operating simultaneously with three time coordinates: the calendar year ( $\mathrm{X}$ axis), the age of people at each moment of time ( $\mathrm{Y}$ axis) and the birth years forming generations (diagonal). This diagram is used to display simultaneously the totality of demographic events in the life of generations.

\section{DATA ANALYSIS}

The visualization of the data on the Lexis grid was preceded by an analysis of the facts of the occurrence of all the events one by one (Appendix 1) and of their median ages (Appendix 2). Then we revealed what event was the first and the last in each biography and calculated the median ages of these events (Appendix 3). The Lexis grid allowed us to visualize all the results and correlate them with the historical context associated with the period of the transition to adulthood of each generation (see the figure below).

The axis of calendar time ( $\mathrm{X}$ axis) gives an idea of the historical context in which each generation has grown up. In the area under the $\mathrm{X}$ axis, we entered some historical events that could have influenced the onset of starting events. We will describe these events and their influence in more detail in the following sections of the article.

The age axis ( $\mathrm{Y}$ axis) begins at the point where respondents reach 15 years of age and ends at the time of their 30th birthday, since the median values obtained are limited to this age. 
The diagonal axis contains information about each generation. Color icons represent the results of event analysis and are located according to the median ages of the onset of starting events (Appendix 2). Pictograms of men are marked in blue, of women - in red. The degree of opacity of the pictograms shows what share of the generation has a specific event. The intervals between the earliest and the latest starting events are combined by a shaded color "corridor". Thus, both the pictograms and the shaded corridors reflect information on the occurrence of the starting events separately (event approach).

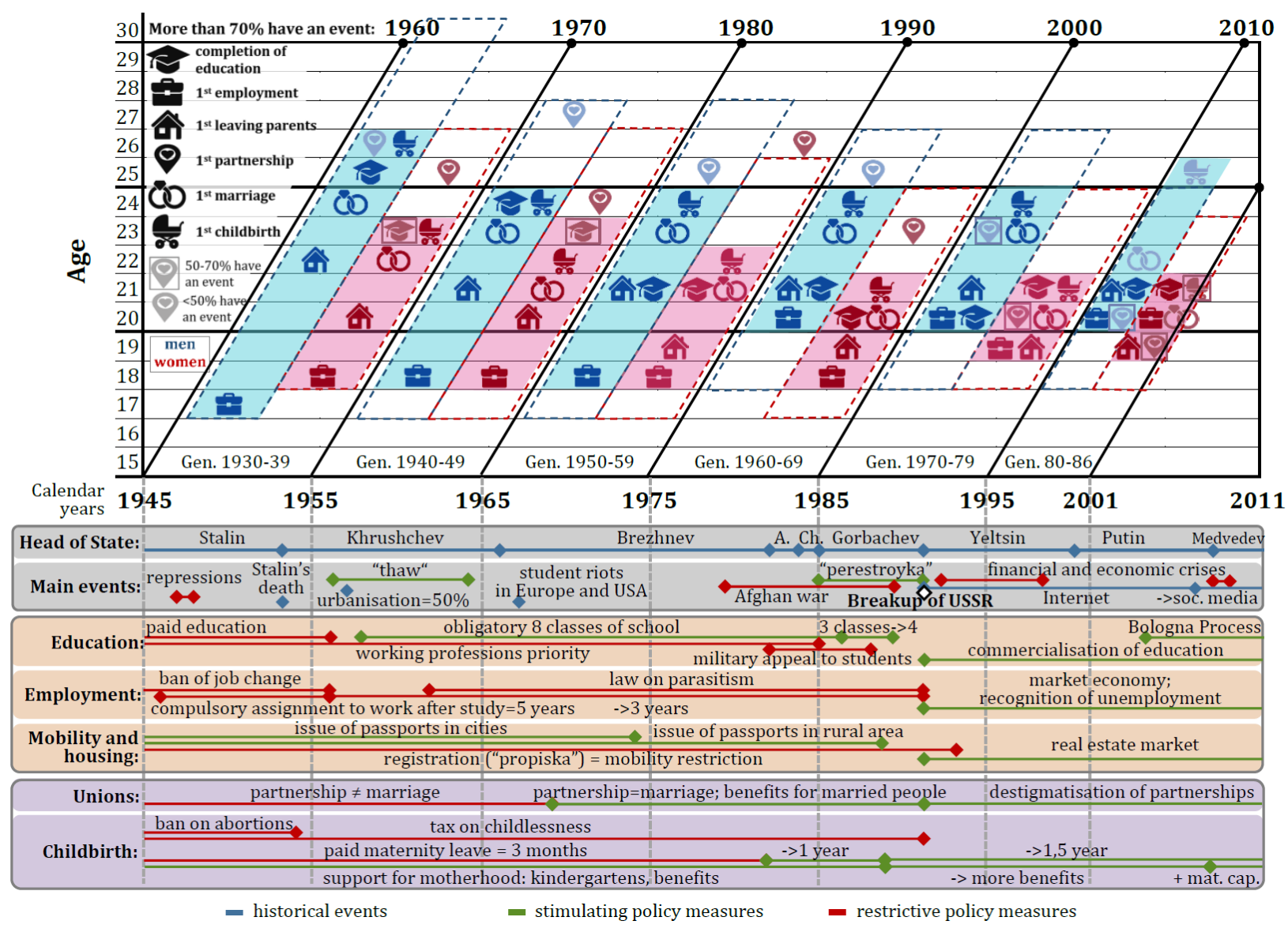

Figure. Visualization of the process of transition to adulthood for different generations of Russians in the existing historical context

Source: Made by the author based on the panel data of the Russian part of GGS for 2011.

Notes: A. - Andropov; Ch. - Chernenko; 3 classes-> 4 - the opportunity to skip the 4th grade of school; -> 1 year - increase in parental leave up to one year; -> 1.5 years - an increase in parental leave up to 1.5 years; matcap - maternal capital.

Notes on the Lexis grid: pictograms indicate the median ages of events; shaded color corridors indicate the boundaries of the occurrence of events separately (event approach); dashed corridors - the intervals between the first and last event of transition to adulthood as a single process (holistic approach); partnerships are not included in the corridors, as they were not mandatory for transition to adulthood in Soviet times.

Information about the onset of all starting events as elements of a single process (holistic approach) is contained in dashed "corridors" that do not coincide with the shaded ones. The lower boundary of such a corridor is defined by the first event (the one with which transition to adulthood begins), and the upper one by the event that occurred last (Appendix 3). 
Neither the shaded nor the dashed corridors include partnership, since it was not part of the normative scenario of transition to adulthood in Soviet times.

The table, compiled on the basis of the described scheme and data on the facts and median ages of the onset of events, summarizes information on six key parameters of transition to adulthood. The indicators in the table do not include partnership. Based on the data on the duration of transition to adulthood and the number of events that have occurred, the "speed", i.e. the average number of events per year, has been calculated (Appendix 4) ${ }^{1}$.

\section{Table. Classification of the models of transition to adulthood in Russia}

\begin{tabular}{|c|c|c|c|c|c|c|c|}
\hline Generation & \begin{tabular}{|c|} 
Age \\
boundaries \\
of transition \\
to \\
adulthood
\end{tabular} & $\begin{array}{c}\text { Duration } \\
\text { of } \\
\text { transition } \\
\text { to } \\
\text { adulthoo } \\
\text { d, years }\end{array}$ & $\begin{array}{c}\text { Number } \\
\text { of } \\
\text { events } \\
\text { out of } 5\end{array}$ & $\begin{array}{c}\text { Number } \\
\text { of } \\
\text { events } \\
\text { per year }\end{array}$ & $\begin{array}{l}\text { Sequence of the first events } \\
\text { occurrence } * *\end{array}$ & \begin{tabular}{|c|} 
Calendar \\
years of \\
transition to \\
adulthood
\end{tabular} & $\begin{array}{l}\text { Models of } \\
\text { transition to } \\
\text { adulthood }\end{array}$ \\
\hline $1930-39$ & $17-27$ & 10 & 4.46 & 0.69 & \multirow{4}{*}{$\begin{array}{l}\text { 1. Employment } \\
\text { 2. Separation from parents } \\
\text { 3. Marriage and childbearing } \\
\text { 4. Professional education } \\
\text { 5. Partnership }\end{array}$} & $1947-1966$ & tional» \\
\hline $1940-49$ & $17-26$ & 9 & 4.57 & 0.80 & & $1957-1975$ & \multirow{3}{*}{ «Soviet» } \\
\hline $1950-59$ & $17-26$ & 9 & 4.66 & 0.81 & & 1967-1985 & \\
\hline 1960-69 & $17-25$ & 8 & 4.63 & 0.95 & & 1977-1994 & \\
\hline 1970-79* & $18-25$ & 7 & 4.51 & 1.06 & $\begin{array}{l}\text { 1. Employment } \\
\text { 2. Separation from parents } \\
\text { 3. Professional education }\end{array}$ & $1988-2004$ & «Transitional» \\
\hline $1980-86 *$ & $18-23$ & 5 & 3.60 & 1.23 & $\begin{array}{l}\text { 4. Partnership } \\
\text { 5. Childbearing } \\
\text { 6. Marriage }\end{array}$ & 1998-2009 & «Post-Soviet» \\
\hline
\end{tabular}

Source: Made by the author based on the panel data of the Russian part of GGS for 2011.

Notes: * For generations that have not completed the transition to adulthood, preliminary results are presented; ** - Designations of universality of occurrence of events: universal events (more than $70 \%$ of respondents have it); semi-universal events (50-70\% of respondents have it); non-universal events (less than $50 \%$ of respondents have it).

Here are the main conclusions for each of the parameters of transition to adulthood presented in the diagram and table.

The boundaries of transition to adulthood are changing very slowly. On average, Russians are characterized by an onset of starting events in the range from 17-18 to 25-27 years. Men begin the transition to adulthood before women and mainly with socio-economic events. Due to the fact that women gain experience more intensively in the demographic sphere and quickly catch up with men in terms of socio-economic events, the transition to adulthood of women is faster. On average, by the age of 25 , both sexes already have experience in two of the three socioeconomic events; the number of demographic events for women is already $1.5-2$, while for men it is only 1.3. By the age of 35 both sexes have 2.5 socioeconomic events, while the number of demographic events is more than two for women and less than two for men.

\footnotetext{
${ }^{1}$ The speed of transition to adulthood is obtained by dividing the number of starting events in the life of a particular individual by the duration of his transition to adulthood. Then, on the basis of individual "speeds" of transition to adulthood, the average "speed" for each generation was calculated. This calculation method gives more accurate results than simply dividing the column "Number of events out of 5" by "Duration of transition to adulthood".
} 
On average, the completion of transition to adulthood among Soviet men occurred by the age of 26-28 years; among Soviet women - about a year earlier. That is, the duration of transition to adulthood was approximately 9-10 years. At the time of the survey, the youngest generation of Russians was at the ages of 25-31, and by that time they had accumulated only 3.6 out of five events, so it is still impossible to calculate the average or median age of completion of transition to adulthood for them.

Since at the time of the survey the respondents were of different ages, they had different chances of starting events. To neutralize this effect, we calculated the relative indicator of the "speed" of transition to adulthood: for each respondent we divided the duration of transition to adulthood by the number of completed events, and then we calculated the average number of events for each generation. The "speed" of transition to adulthood shows that the oldest generation grew up the most "slowly" of all ( 0.69 events per year). The youngest generation, which began the transition to adulthood just a few years ago, shows an almost 2 times higher growth rate (1.23 events per year). Of course, this is due to the effect of age: the older the generation becomes, the lower the growth rate will be.

Having arranged the starting events in chronological order within each biography, we determined the averaged sequence of their occurrence. Calculations confirm the empirical evidence already available that the prevalence and sequence of the onset of starting events among Russians is changing (Mills 2004; Zakharov 2009; Potârcă et al. 2013).

In Soviet times, the universal events were employment, separation from parents and the creation of a family, and they occurred mainly in this sequence. Getting a professional education was to a greater extent the prerogative of men. For women, this event is included in the normative scenario of transition to adulthood starting only from the generation born in 1950-59. Entering a partnership (an unregistered union) in Soviet society was not encouraged, so it is rare. And if this event did take place, it was mainly after a first marriage and subsequent divorce. That is, in Soviet times, partnership did not fulfill the role of a marker of the onset of adulthood, but rather was an acceptable event within it.

The onset of starting events in the context of other individual characteristics did not differ much. For the vast majority of respondents, the first event was employment, and the last was procreation. For highly educated respondents and residents of regional centers, the first event often became separation from parents, most likely related to educational or labor mobility. And the last event (along with childbearing) was getting a professional education. For women, the appearance of a child reduced the chances of finding a job and getting a professional education.

In the post-Soviet era, partnerships and professional education became part of the normative scenario of transition to adulthood. Adding these two events to the list of mandatory and/or desirable ones has increased the diversity of combinations of starting events. Today's young people, who have a high level of education and live in regional centers, begin their transition to adulthood with socio-economic events, that is, with investments in their human capital and the gaining of financial independence. Only after this do the young generations start a family. Moreover, their family life most often begins with a partnership that does not always turn into marriage, even with a child. The sequence of events for those who live in less urbanized areas and have a lower level of education varies by gender: the beginning of the transition to adulthood in 
men is now associated more with getting an education (often in combination with employment), and for women, with a partnership or marriage.

\section{CALENDAR YEARS: LOCATING A GENERATION'S TRANSITION TO THE PERIOD OF ADULTHOOD IN A SPECIFIC HISTORICAL CONTEXT}

For the generation born in 1930-39, the most active period of accumulation of starting events was in the period from 1947 to 1966 . These respondents began transition to adulthood in a pivotal era, when the latest wave of post-war repressions and intensification of restrictive measures gave way to a "thaw", a liberalization of socio-economic, educational, labor, migration and family policy. At the same time, liberalization was inconsistent and far from complete: the obvious features of universal labor mobilization persisted, and a policy of "workerfication", with mandatory job placement after completion of studies and the prohibition of quitting or changing jobs, was in effect. Nor should we forget about paid tuition in high school, secondary special and higher educational institutions (in effect in 1940-1956), and longer military service in the army. The generation under consideration began the transition to adulthood precisely with employment and postponed other events to later ages.

During this period, there were still no standards for the duration of compulsory schooling, so in this generation there are those who finished only a few grades of school and did not receive a higher education, or who received one, but late, as one of the last events in the chain of events marking transition to adulthood.

The post-war imbalance of the sexes, leading to an imbalance in the marriage market, contributed to a serious discrepancy in the median ages of the onset of demographic events for men and women. Demographic events in this generation came later than in subsequent generations. Among other things, this was caused by the intense competition for time between family and work life, as well as by the newly formed and not yet well-functioning institutions of state welfare (nurseries, kindergartens, short maternity leave, etc.).

The generations born in 1940-49 and 1950-59 transitioned to adulthood in a more stable period of Soviet history (1957-1985). Public life was still highly regulated. There were quite a few restrictive measures, but state support for family, education and other spheres of life grew and gave confidence that state institutions would help to bring about the necessary events and successfully master new social roles. Existing "Soviet" norms and rules had already been mastered by previous generations, which facilitated the transmission of normative behavior scenarios.

Respondents born in the 40s and 50s made the transition to adulthood early and fast. The onset of starting events in men occurred at the age of 27 years, in women - at 25-26 years. The average sequence of their onset looked like this: first, employment and separation from parents, then starting a family and completing one's professional education. The relationship between getting married and having children was very strong (the protogenetic interval - the time between getting married and having a first child - was less than a year). This uniformity of the onset of starting events reflected the uniformity of views, living conditions and income, and the existence of uniform social and legislative norms governing the time and sequence of occurrence of events. 
The generation born in 1960-69 began the transition to adulthood in stable Soviet times (1977), and ended it during the period of perestroika and the collapse of the Soviet Union (1994). As a result, the process of transition to adulthood (the sequence and timing of the onset of events) for this generation looks outwardly very similar to its predecessors, but a more detailed examination of, in particular, gender differences allows us to see emerging changes, largely due to situational factors (changes in socioeconomic and demographic policies).

For men of this generation, starting events occur later than for their predecessors. To some extent, this is due to the fact that in the 1960s the size of birth cohorts decreased, which means that 18 years later the number of draftees also became smaller than in previous years. In order to compensate for the reduction in the contingent of conscripts for military service, in the $80 \mathrm{~s}$ a number of deferments for those entering institutions of higher education were suspended, and the number of ministries able to grant deferments to graduates of vocational schools for the duration of their work in the national economy was limited [Gradoselsky, 2005]. After completing military service and returning home, men began to "catch up" with what was lost and completed transition to adulthood even a year earlier than previous generations.

Women of this generation also demonstrate an earlier completion of transition to adulthood, due to a decrease in the age at birth of a first child. In 1982, the government increased paid parental leave to 1 year, and in 1989 to one and a half years. These measures stimulated fertility among women born in the 60s, while at the same time lowering their chances of receiving a higher education and employment.

The generation born in 1970-79 entered adulthood in a very turbulent time (1988-2004), with blurry guidelines regarding desirable, undesirable and mandatory patterns of behavior. Along with the tremendous expansion of freedom of choice of behavioral practices, the ability to try new things and experiment, the level of uncertainty, tension and risks also grew: this generation was faced with economic crises, military operations in Chechnya and inter-ethnic conflicts, and the instability of social institutions throughout the transition to the adulthood period - with, that is, the inevitability of adjustments of their plans for the future.

The abolition of restrictive norms in the socioeconomic and demographic sphere allowed this generation to organize their life more freely, but in conditions of rather high turbulence and uncertainty: a number of professions and specializations ceased to be in demand, and key enterprises and organizations closed and/or changed their form of ownership, which caused disorientation and often unemployment, especially among the younger generation, who did not yet have experience in employment and social relations. As a result, there was a postponement of the age of first employment in this generation.

The increase in the accessibility of higher education, including through its commercialization, caused a sharp increase in the supply and demand for educational services. As a result, an increasing number of young people were able to afford a "psychosocial moratorium" (Erikson 1995) as students, higher education for them being not so much an investment in human capital as a way of "waiting out" the next economic crisis and period of uncertainty. 
The age of leaving the parental home for those born in the 70s coincides with the timing of previous generations, since the state continued, by inertia, to fulfill a number of social obligations, in particular, by providing housing for those who had been on a "waiting list for improved housing conditions" since Soviet times. During this period, older ways of obtaining housing (for example, hostels, apartments of a "hotel type" from employers) were dying out, and were being replaced by new ones as a result of the increasing development of a flexible housing market, as well as to the weakening of socio-regulatory and legislative restrictions on living with "outsiders" (i.e. with partners).

The age of entry into the first partnership of this generation decreased markedly, and the number of such unions in the course of life, in comparison with previous generations, increased. The gradual destigmatization of premarital sexual relations allowed this generation to master new ways of living together. However, a lack of knowledge about family planning and contraception often led to premarital conceptions. Previous generations in this situation either got married after a pregnancy - "shotgun weddings" - or aborted. Generations of the 70s, however, were less likely to resort to abortion, choosing instead to keep the child, but the practice of marriage after conception continued to be reproduced. Therefore, the protogenetic interval remains at the level of previous generations (less than a year).

The generation born in 1980-86 is the only one of all the generations under consideration which began the transition to adulthood some time after the collapse of the USSR (they reached the age of 15 in 1995 or later) and for which the expanded freedom of choice and the new information environment were natural components of life. The economically fairly stable aughts, the restoration of institutions of state support for the family, the openness of state borders, the possibility of renting and buying housing - these and other factors created the conditions for a more varied, but at the same time protected entry into adulthood. The emergence of the Internet, social networks, the possibilities of remote work or a freer schedule, the development of the pharmacological market allowed this generation to successfully master new skills in life and family planning, to study various options for forming a life path based on the principles of time management and informed choice. The absence of a unified and rigidly fixed pattern of behavior has led to an increase in the diversity of life strategies, in particular, demographic ones, to the possibility of rejecting some events, for example, childbearing (Vildanova et al. 2017; Salyakhieva, Saveleva 2017), or delaying them, or, on the contrary, more effectively combining events from different spheres of life, for example, parenthood and employment (Billari, Giuntella, Stella 2019).

Standard socioeconomic events for the generation born in the 80s occur at about the same ages and with the same intensity as in the previous two generations. The age of the first employment is somewhat delayed, but this is due to the longer professional education. Among the first demographic events, partnerships are more often preferred, while events requiring a more long-term responsibility (marriage and childbearing) are postponed to later ages. While for men a slowdown in the pace of demographic transition to adulthood is very clearly visible, the life paths of women are still very "compressed" (less than for women of the previous generation, but much more than for their male peers). 
Young people are not shying away from transition to adulthood; rather, by becoming an active participant in this process, they are beginning to change its structure and calendar. Due to the wide accessibility of higher education, it has become possible to include student years in a young Russian's typical life scenario. And this, according to E. Erickson (Erikson 1995), gives individuals the opportunity to take a break between ending their childhood and reaching adulthood (a "psychosocial moratorium") and devote this time to finding themselves and planning a career.

\section{THE CLASSIFICATION OF TRANSITION TO ADULTHOOD MODELS}

The proposed method for visualizing the process of transition to adulthood on the Lexis demographic grid allows us to conclude that the era in which a generation actualizes the starting events of adulthood influences the formation of models of growing. The transition to adulthood is a changing stage of life, adapting to specific environmental conditions and helping the young generation to most effectively and quickly integrate into the existing social system.

The organization of the process of the transition to adulthood among the generations of 1940-49, 1950-59, and 1960-69 can be called the most stable and typical model. We call this model "Soviet". A typical transition to adulthood appeared only as a result of the unification of the work of social institutions in the late Soviet era. In the era of a planned economy and a planned organization of life, the normative life scenario was very clearly defined. It was easy to follow, since all the institutions worked in concert and focused on this particular model.

In periods of change and instability, individuals delay the onset of some events and prioritize the onset of others. For example, the generation born in 1930-39, faced with the postwar devastation and the economic difficulties associated with it, was forced to make labor a priority, postponing other events to later ages. For the generation born in 1970-79, the opposite occurred: in a period of rapid social and political transformations and an inability to make reliable plans for the future, it actualized key starting events "in an accelerated mode", either "making reserves for the future" or striving to try everything at once in conditions of unprecedented freedom. Such models of transition to adulthood can be called "Transitional" (or adaptive, responsive). They best demonstrate the adaptive nature of the transition to adulthood process.

The model of transition to adulthood which is developing among today's youth (those born in 1980-86) we will call "Post-Soviet". We are now seeing a slowdown in the process of transition to adulthood due to the postponement of the onset of demographic events, which was made possible thanks to access to information and technologies (family planning and contraception; expansion of the set of regulatory models broadcast through the media). Other important changes include the addition of a new normative event (partnership) and the prioritization of an event that was previously less important and affordable (getting a higher professional education). This leads not only to a change in the timing and sequence of occurrence of events, but also to an increase in the number of starting events and the variety of sets of possible life scenarios. The vector of changes chosen by Russian youth corresponds to the path of transformation of adult models in Western countries described by authoritative foreign authors (Billari, Liefbroer 2010): transition to adulthood is no longer "early, contracted and simple" and becomes "late, protracted and complex". 


\section{DISCUSSION OF RESULTS}

The comprehensive analysis and classification presented by us confirm the ideas of Billari and Liefbroer (Billari, Liefbroer 2010) on the convergence of transition to adulthood patterns in developed countries. Modern Russian generations that began the transition to adulthood after the collapse of the USSR have moved away from the typically "Soviet" model of transition to adulthood, which can be called "early, contracted and simple" (the "traditional" model) and are approaching the model that is becoming more common in Western countries: "late, protracted and complex" (the "modern" model). Transition to adulthood is beginning later, as young people postpone the onset of all events, and especially demographic ones. Transition to adulthood is becoming more protracted, as socio-economic events are realized only a year or two later than in previous generations and demographic events are postponed for several years, which causes an increase in the overall duration of the transition and a slowdown in its speed. Transition to adulthood is becoming more complex due to the increase in the variability of time and sequence of occurrence of events and the inclusion of two formerly unpopular events in the normative life scenario: professional education and partnership.

The transition from the "traditional" "Soviet" model of transition to adulthood among Russians to a "modern" "Post-Soviet" one confirms the historical stadiality of changes in the process of transition to adulthood and of demographic behavior as part of it (Frejka, Zakharov 2012; Puur et al. 2012a; Puur et al. 2012b). We found that changes in the timing and tempo of the onset of starting events began in the generation born in 1960-69, but that these transformations were linked with historical and political events of the period: the war in Afghanistan, the activation of family policy and the stimulation of fertility in the 1980s. The first sustainable, generational changes begin with the generations born in 1970-1979, whose members began to change not only the timing and tempo of the onset of events, but also their sequence and priority relative to each other. The generation born in 1980-1986 demonstrates a fundamentally different approach to organizing the process of transition to adulthood, highlighting those events that provide more benefits than obligations, and putting off events requiring long-term responsibility.

The study also confirms the estimates made by the above authors of the difference between the beginning of demographic modernization in Europe and in Russia: while in Western European countries changes in matrimonial behavior began in the generation of those born in 1960-69, in Russia they began 20-25 years later, in the 1980-86 generation. The cluster of three types of behavior - sexual, mating and reproductive - is gradually breaking up: the debuts of each of them not only turn out to be separated by longer intervals, but also occur in an increasingly arbitrary sequence. The first partnership among young Russians is increasingly becoming the first demographic event, childbearing is the second, and marriage either occurs shortly after the conception of a child or may not occur at all, which leads to an increase in extramarital births and a decrease in marriage.

An increase in the diversity of life strategies, a change in the sequence of events and the intervals between them, the emergence of the opportunity to organize your life path in accordance with your own interests - all this is observed in the younger generation of Russians and is consistent with the assumptions of the concept of a life course (Giddens 1994; Heinz, Marshall 2003; Huinink 2013). 


\section{Conclusions}

The study showed that the historical and institutional context accompanying the transition to adulthood of young people sets the boundaries and guidelines for possible models of transition to adulthood (Berger, Luckmann 1966; Kiernan 2002; Sobotka, Toulemon 2008). The greater the support of the state, the earlier and more intensive transition to adulthood occurs, which is consistent with existing studies (Cavalli, Galland 1993; Vogel 2002; Esping-Andersen 2007; Ejrnœs, Boje 2008). The narrower the corridors formed by social and legislative norms, the fewer differences in the structure, timing, tempo and sequence of occurrence of starting events (examples are the generations born in 1940-49, 1950-59, 1960-69). With the expansion of freedom of choice in organizing life paths, young people begin to demonstrate variability of all types of behavior (for example, generations born in 1980-86).

We have identified three models of transition to adulthood of Russians: "Soviet" (typical for generations of 1940-49, 1950-59, 1960-69), "Transitional" (generations 1930-39 and 1970-79) and "Post-Soviet" (generations 1980-86). The proposed models fit into the classification of Billari and Liefbroer (Billari, Liefbroer 2010): the "Soviet" model corresponds to the "traditional" one (timing - events occur at young ages; tempo - small intervals between events; sequence of events is simple and predictable), and the "Post-Soviet" one is approaching the "modern" (timing postponing events to later ages; tempo - increasing intervals between events; the sequence of events is complex and unpredictable). Thus, there is a convergence of the features of the transition to adulthood in Russia and in countries that are at more advanced stages of the demographic transition, which confirms the stadiality of the modernization process (Frejka, Zakharov 2012; Puur et al. 2012a; Puur et al. 2012b).

The average "modern" model of transition to adulthood in Europe looks like this: relatively early leaving of the parental home, followed by a short time without a partner, then entering into a partnership, conception of the first child at a relatively young age and registering a marriage shortly before the birth of the child or even choosing not to register the marriage at all (Billari, Liefbroer 2010). Our analysis showed that the sequence of starting events for Russian youth is approaching the modern European one, but demographic events in Russia occur at earlier ages and with shorter intervals. That is, the composition of transition to adulthood in Russia is becoming similar to the European model, but the dynamics are still different.

The inclusion of student years in the normative life scenario of a modern Russian has made it possible for young people to use their student years and the subsequent period of starting a career as a pause in the transition to adulthood (so called "psychosocial moratorium" (Erikson 1995)). During these several years, young Russians are in a "half-grown-up" state: they have already acquired socioeconomic statuses and experience living with a partner, but have not yet created a family. Marriage and childbearing are perceived by them as the most "irreversible" events, requiring a certain psychological maturity and financial stability. We believe that this lengthening of the period of transition to adulthood is a consequence of the postponement of demographic events to later ages, and not a complete rejection of them.

The present study helps to better understand what modern youth is and in what age segment it is localized. Given the desire of young people to achieve financial independence before marriage and childbearing, as an effective measure might be proposed the expansion of financial instruments 
and career opportunities that will allow young people not to linger in the "half-grown-up" period. A more flexible system of combining parenthood and employment will also help achieve a balance between the socioeconomic and demographic spheres. By turning to the available examples of the transformation of transition to adulthood models in European countries, we can predict further changes in transition to adulthood in Russia and, by anticipating them, prepare society and institutions for new challenges.

\section{ACKNOWLEDGMent}

This paper is an output of a research project implemented as part of the Basic Research Program at the National Research University Higher School of Economics (HSE University).

I would like to thank some colleagues for their many years of support which helped this research to come to fruition. First and foremost, I express heartfelt gratitude to S.V. Zakharov for his continual scientific advising, insightful recommendations and openness to new ideas.

I thank the teams of the HSE Research and Study Groups "Fertility, Family Formation and Dissolution" and "Models and Methods of Demographic Sequence Analysis", especially A.O. Makarentseva, D.I. Ignatov, T.H. Espy, A.V. Artamonova, A.A. Muratova, D.K. Gizdatullin, O.V. Sinyavskaya, S.S. Biryukova and A.A. Dolgova.

I express genuine thanks to Russian and foreign colleagues for their consultations and reviews of the different parts of my research: A.G. Vishnevsky, M.B. Denisenko, V.S. Magun, A. Puur, A. Blum, F.C. Billari, M. Mills, L. Sakkeus, L. Rahnu, G. Ritschard, M.S. Fabrykant, A.A. Avdeev, P. Blanchard, R. Leu, L. Toulemon, E. Lelièvre, M. Bouchet-Valat and L. Moulin.

\section{REFERENCES}

Arkhangel'skij V.N. (2013). Reproduktivnoe i brachnoe povedenie [Reproductive and marital behavior]. Sociologicheskie issledovaniya [Sociological studies], 2, 129-136. (In Russ.).

Arnett J.J. (2012). New Horizons in Research on Emerging and Young Adulthood. In Early Adulthood in a Family Context (pp. 231-244). NY: Springer.

Artamonova A.V., Mitrofanova E.S. (2014). Is cohabitation an alternative to marriage in Russia? Political behavior: Race, Ethnicity \& Identity Politics eJournal. 8(134). URL: https://hq.ssrn.com/Journals/IssueProof.cfm?abstractid=2513302\&journalid=999052\&issue_ number $=134 \&$ volume $=8 \&$ journal_type $=\mathrm{CMBO} \&$ function $=$ showissue

Artamonova A.V., Mitrofanova E.S. (2018). Matrimonial'noe povedenie rossiyan na fone drugih evropejcev [Matrimonial behavior of Russians in the European context]. Demograficheskoe obozrenie [Demographic Review], 5(1), 106-137. (In Russ.).

Berger P., Luckmann T. (1966). The Social Construction of Reality: A Treatise in the Sociology of Knowledge. Garden City, NY: First Anchor.

Billari F.C., Giuntella O., Stella L. (2019). Does broadband Internet affect fertility? Population Studies, 73(3), 297-316. DOI: https://doi.org/10.1080/00324728.2019.1584327

Billari F.C., Hagestad G.O., Liefbroer A.C., Spéder Z. (2005). The Timing of Life: The Organization of the Life Course in Europe. In The timing of life: The organisation of the life 
course in Europe. URL:

http://www.europeansocialsurvey.org/docs/round3/questionnaire/ESS3_billari_proposal.pdf

Billari F.C., Liefbroer A.C. (2007). Should I Stay or Should I Go? The Impact of Age Norms on Leaving Home. Demography, 44(1), 181-198. URL:

https://link.springer.com/article/10.1353\%2Fdem.2007.0000

Billari F.C., Liefbroer A.C. (2010). Towards a new pattern of transition to adulthood? Advances in Life Course Research, 15(2), 59-75.

Blum A., Lefèvre C., Sebille P., Badurashvili I., Régnier-Loilier A., Stankuniene V., Sinyavskaya O. (2010). Sem'ya v chetyrekh gosudarstvah: Franciya, Gruziya, Litva, Rossiya [Family in four states: France, Georgia, Lithuania, Russia]. In Evolyuciya sem'i v Evrope: Vostok-Zapad [Evolution of the Family in Europe: East-West] (pp. 11-41). Moscow: NISP. (In Russ.).

Blum A., Sebij P., Zakharov S.V. (2010). Vzroslenie vo Francii i Rossii: Razlichiya v perspektive pokolenij [Transition to adulthood in France and Russia: Differences in generational perspective]. In Evolyuciya sem'i v Evrope: Vostok-Zapad [Evolution of the Family in Europe: East-West] (pp. 141-174). Moscow: NISP. (In Russ.).

Buchmann M. (1989). The script of life in modern society: Entry into adulthood in a changing world. Chicago: University of Chicago Press.

Buchmann M.C., Kriesi I. (2011). Transition to Adulthood in Europe. Annual Review of Sociology, 37, 481-503. DOI: https://doi.org/10.1146/annurev-soc-081309-150212

Cavalli A., Galland O. (Eds.) (1993). L'allongement de la jeunesse. Paris: Actes Sud.

Chernova Zh.V. (2012). Specifika gendernyh otnoshenij molodyh vzroslyh [Specificity of gender relations of young adults]. Sociologicheskie issledovaniya [Sociological Studies], 7, 118-127. (In Russ.)

Dolbik-Vorobej T. (2003). Studencheskaya molodezh' o problemah braka i rozhdaemosti [Student youth about the problems of marriage and fertility]. Sociologicheskie issledovaniya [Sociological Studies], 11, 78-83. (In Russ.).

Ejrnœs A., Boje T.P. (2008). Family Policy and Welfare Regimes. In Report 3: Labour Market and social Policies. Aberdeen: University of Aberdeen.

Erikson E.H. (1995). Identity: Youth and Crisis. New York: W.W. Norton \& Company.

Esping-Andersen G. (1990). The Three Worlds of Welfare Capitalism. NJ: Polity Press.

Esping-Andersen G. (2007). Family formation and family dilemmas in contemporary Europe. Fundacio'n BBVA.

Frejka T., Zakharov S. (2012). Comprehensive analyses of fertility trends in the Russian Federation during the past half century. Rostock: Max Planck Institute for Demographic Research (MPIDR working paper WP-2012-027).

Giddens A. (1994). Living in a post-traditional society. Reflexive modernization: Politics, tradition and aesthetics in the modern social order, 56, 100.

Gimpel'son V.E., Zudina A.A. (2017). Demograficheskie problemy rynka truda [Demographic problems of the labour market]. Demoscope Weekly, 729-730. (In Russ.). URL: http://www.demoscope.ru/weekly/2017/0729/tema01.php 
Gradoselskiy V. (2005). Komplektovanie vooruzhennih sil SSSR v 1970 - 1980-e gody [Completion of Soviet Union armed forces in 1970-1980]. Voenno-istoricheskiy zhurnal [War-historical Journal], 9, 18-21. (In Russ.).

Hajnal J. (1965). European marriage patterns in perspective. In Glass D.V., Eversley D.E. (Eds.), Population in history: Essays in historical demography (pp. 101-143). URL: https://www.popline.org/node/517620

Heinz W.R., Marshall V.W. (2003). Social dynamics of the life course: Transitions, institutions, and interrelations. New York: Aldine de Gruyter.

Huinink J. (2013). De-Standardisation or Changing Life Course Patterns? Transition to Adulthood from a Demographic Perspective. In The Demography of Europe (pp. 99-118). Springer, Dordrecht. DOI: https://doi.org/10.1007/978-90-481-8978-6_5

Inglhart R. (2018). Kul'turnaya evolyuciya. Kak izmenyayutsya chelovecheskie motivacii i kak eto menyaet mir [Cultural evolution. How human motivations change and how it changes the world]. (In Russ.). URL: https://sotsium.ru/uploads/files/demo-mysl/inglehart_p1-40.pdf

Kiernan K. (2002). Cohabitation in Western Europe: Trends, issues and implications. In Booth A., Crouter A. (Eds.), Just Living Together: Implications of cohabitation on families, children and social policy (pp. 3-31). New York: Lawrence Erlbaum Associates.

Konstantinovskij D.L. (2008). Neravenstvo i obrazovanie. Opyt sociologicheskih issledovanij zhiznennogo starta rossijskoj molodezhi (1960-e gody-nachalo 2000-h) [Inequality and education. Experience of sociological research of life start of Russian youth (1960s-early 2000s)]. Moscow: Centr social'nogo prognozirovaniya. (In Russ.)

Lapeto A., Tereshchenko O.V., Shaverdo T. (2018). Perekhod v samostoyatel'nuyu zhizn': Vozrastnye modeli zhiznennyh putej [Transition to independent life: Age models of life paths]. In O. Tereshchenko, T. Kuchera (Eds.), Belarus': Struktura sem'i, semejnye otnosheniya, reproduktivnoe povedenie: Tom II. Analiz rezul'tatov issledovaniya «Pokoleniya $i$ gender» [Belarus: Family structure, family relations, reproductive behavior: Vol. II. Analysis of the results of Generations and Gender Survey] (pp. 14-22). Minsk: Belsens. (In Russ.)

Lesthaeghe R. (1995). The second demographic transition in Western countries: An interpretation. In Gender and family change in industrialized countries (pp. 17-62). Oxford: Clarendon Press.

Lesthaeghe R., Neels K. (2002). From the First to the Second Demographic Transition: An Interpretation of the Spatial Continuity of Demographic Innovation in France, Belgium and Switzerland European. Journal of Population, 18(4), 325-360.

Liefbroer A.C. (1999). From Youth to Adulthood: Understanding Changing Patterns of Family Formation from a Life Course Perspective. In Population Issues (pp. 53-85). The Netherlands: Springer.

Magun V.S., Engovatov M.V. (2006). Dinamika prityazanij i izmenenie resursnyh strategij molodezhi: 1985-2005 gody [Trends in claims and changes in resource strategies of young people: 1985-2005]. Otechestvennye zapiski [Annals of the Fatherland], 3, 76-96. (In Russ.)

Mead M. (1988). Kul'tura i mir detstva [Culture and the world of childhood]. Moscow: Nauka. (In Russ.)

Mills M. (2004). Stability and change: The structuration of partnership histories in Canada, the Netherlands, and the Russian Federation. European Journal of Population/Revue européenne de Démographie, 20(2), 141-175. 
Potârcă G., Mills M., Lesnard L. (2013). Family Formation Trajectories in Romania, the Russian Federation and France: Towards the Second Demographic Transition? European Journal of Population/Revue européenne de Démographie, 29(1), 69-101. DOI: https://doi.org/10.1007/s10680-012-9279-9

Puur A., Rahnu L., Maslauskaite A., Stankuniene V. (2012a). Past and present patterns of family formation in Eastern Europe: Does Hajnal's delineation still matter? Filosofija Sociologija, 23(4), 256-265.

Puur A., Rahnu L., Maslauskaite A., Stankuniene V., Zakharov S. (2012b). Transformation of Partnership Formation in Eastern Europe: The Legacy of the Past Demographic Divide. Journal of Comparative Family Studies, 43(3), 389-417.

Remshmidt H. (1994). Podrostkovyj i yunosheskij vozrast: Problemy stanovleniya lichnosti [Adolescence and youth: Problems of personality formation]. (In Russ.) URL: http://www.childpsy.ru/lib/books/id/8335.php

Rindfuss R.R. (1991). The Young Adult Years: Diversity, Structural Change, and Fertility. Demography, 28(4), 493-512. URL: https://link.springer.com/article/10.2307\%2F2061419

Salyakhieva L.M., Saveleva Z.V. (2017). Childfree as a Social Phenomenon: Russians' Attitude to Voluntary Childlessness. Tarih Kültür ve Sanat Araştırmaları Dergisi, 6(4), 531-537. DOI: https://doi.org/10.7596/taksad.v6i4.1144

Shabunova A.A., Kalachikova O.N. (2015). Problemy transformacii demograficheskih institutov: Sem'ya i brak [Challenges to the transformation of demographic institutions: Family and marriage]. Sociologicheskij al'manah [Sociological almanac], 6, 151-165. (In Russ.)

Shoven J.B., Goda G.S. (2011). Adjusting Government Policies for Age Inflation. In Demography and the Economy (pp. 143-168). DOI: https://doi.org/10.7208/chicago/9780226754758.003.0005

Sobotka T., Toulemon L. (2008). Changing family and partnership behaviour: Common trends and persistent diversity across Europe. Demographic Research, 19, 85-138. DOI: https://doi.org/10.4054/DemRes.2008.19.6

van de Kaa D. J. (1987). Europe's Second Demographic Transition. Population Bulletin, 42, 3 57.

Vil'danova S.M., Granichnaya A.A., Mingalieva A.R., Salyahieva L.M. (2017). Tendencii rasprostraneniya cennostej chajldfri v Rossii i ih vliyanie na krizis instituta sem'i [Trends in the spread of childfrey values in Russia and their impact on the crisis of the institution of the family]. Monitoring obshchestvennogo mneniya: Ekonomicheskie i social'nye peremeny [Monitoring of Public Opinion: Economic and Social Changes Journal], 3(139), 192-205. (In Russ.).

Vishnevsky A.G. (1976). Demograficheskaja revolutsija. Moscow: Statistics. (In Russ.).

Vishnevsky A.G. (Ed.) (2006). Demograficheskaja modernizacija Rossii, 1900-2000 [Demographic modernization of Russia, 1900-2000]. Moscow: Novoe izdatel'stvo. (In Russ.).

Vogel J. (2002). European Welfare regimes and the transition to adulthood: A comparative and longitudinal perspective. Social Indicators Research, 59, 275-299.

Yarskaya-Smirnova E.R., Romanov P.V. (Eds.) (2008). Sovetskaya social'naya politika: sceny $i$ dejstvuyushchie lica, 1940-1985 [Soviet social policy: scenes and actors, 1940-1985]. Moscow: OOO Variant, CSPGI. (In Russ.) 
Zakharov S. (2008). Russian Federation: From the first to second demographic transition. Demographic Research, 19, 907-972. DOI: https://doi.org/10.4054/DemRes.2008.19.24

Zakharov S.V. (2007). Transformaciya brachno-partnerskih otnoshenij v Rossii: «zolotoj vek» tradicionnogo braka blizitsya $\mathrm{k}$ zakatu? [Transformation of marriage-partnership relations in Russia: the "golden age" of traditional marriage is nearing sunset?]. In T.M. Maleva, O.V. Sinyavskaya (Eds.), Roditeli i deti, muzhchiny $i$ zhenshchiny $v$ sem'e i obshchestve [Parents and children, men and women in the family and society]. Vol. 1 (pp. 75-127). Moscow: NISP. (In Russ.).

Zakharov S.V. (2009). Cennostno-normativnye «raspisaniya» chelovecheskoj zhizni: Predstavleniya zhitelej raznyh stran o tom, kogda devushka stanovitsya vzrosloj [Valuenormative "schedules" of human life: Perceptions of people in different countries about when a girl becomes an adult]. In Rossiya v Evrope. Po materialam mezhdunarodnogo proekta «Evropejskoe social'noe issledovanie». [To Russia in Europe. Based on the international project "European Social Study"] (pp. 347-379). Moscow: Academia. (In Russ.).

Zdravomyslova O. M., Shurygina I.I. (2001). Vyzhit' ili preuspet': Predstavleniya starsheklassnikov o svoih zhiznennyh shansah [Survive or succeed: High school students "perceptions of their life chances]. In Kto i kuda stremitsya vesti Rossiyu? Aktory makro-, mezo- i mikrourovnej sovremennogo transformacionnogo processa [Who and Where Does Russia Seek to Lead? Actors of macro-, meso- and micro-levels of the modern transformation process] (pp. 366-374). (In Russ.). URL: http://ecsocman.hse.ru/data/250/679/1219/048.Zdravomyslova.pdf

Zsolt S., Murinkó L., Settersten Jr.R.A. (2014). Are Conceptions of Adulthood Universal and Unisex? Ages and Social Markers in 25 European Countries. Social Forces, 92(3), 873-898. DOI: https://doi.org/10.1093/sf/sot100 


\section{APPENDICES}

Appendix 1. The number of respondents for whom each of the starting events occurred or did not occur, by gender and generation

\begin{tabular}{|c|c|c|c|c|c|c|c|c|c|c|c|c|c|}
\hline \multirow{2}{*}{ Events } & \multirow{2}{*}{ Generations } & \multicolumn{6}{|c|}{ Men } & \multicolumn{6}{|c|}{ Women } \\
\hline & & $0-14$ & $15-24$ & $25-34$ & $35+$ & No events & total & $0-14$ & $15-24$ & $25-34$ & $35+$ & No events & total \\
\hline \multirow{6}{*}{ 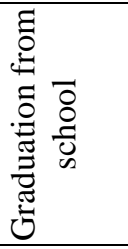 } & $1930-39$ & 52 & 141 & 0 & 0 & 0 & 193 & 144 & 444 & 0 & 0 & 1 & 589 \\
\hline & $1940-49$ & 32 & 184 & 0 & 0 & 0 & 216 & 56 & 498 & 0 & 0 & 0 & 554 \\
\hline & $1950-59$ & 16 & 377 & 0 & 0 & 0 & 393 & 37 & 903 & 0 & 0 & 0 & 940 \\
\hline & $1960-69$ & 23 & 410 & 0 & 0 & 0 & 433 & 32 & 740 & 0 & 0 & 0 & 772 \\
\hline & $1970-79$ & 49 & 293 & 0 & 0 & 0 & 342 & 53 & 552 & 0 & 0 & 0 & 605 \\
\hline & $1980-86$ & 19 & 162 & 0 & 0 & 0 & 181 & 13 & 220 & 0 & 0 & 0 & 233 \\
\hline \multirow{6}{*}{ 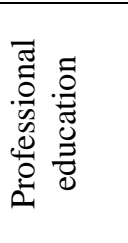 } & $1930-39$ & 0 & 79 & 50 & 30 & 34 & 193 & 0 & 203 & 93 & 51 & 242 & 589 \\
\hline & $1940-49$ & 0 & 98 & 47 & 28 & 43 & 216 & 0 & 246 & 102 & 42 & 164 & 554 \\
\hline & $1950-59$ & 0 & 227 & 83 & 15 & 68 & 393 & 0 & 566 & 152 & 65 & 157 & 940 \\
\hline & $1960-69$ & 0 & 276 & 65 & 25 & 67 & 433 & 0 & 523 & 84 & 42 & 123 & 772 \\
\hline & $1970-79$ & 0 & 244 & 54 & 5 & 39 & 342 & 0 & 390 & 125 & 21 & 69 & 605 \\
\hline & $1980-86$ & 0 & 136 & 20 & 0 & 25 & 181 & 0 & 173 & 32 & 0 & 28 & 233 \\
\hline \multirow{6}{*}{ 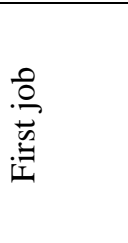 } & 1930-39 & 23 & 160 & 9 & 1 & 0 & 193 & 57 & 488 & 39 & 5 & 0 & 589 \\
\hline & $1940-49$ & 11 & 194 & 9 & 2 & 0 & 216 & 16 & 511 & 24 & 3 & 0 & 554 \\
\hline & $1950-59$ & 4 & 367 & 20 & 1 & 1 & 393 & 5 & 907 & 25 & 1 & 2 & 940 \\
\hline & $1960-69$ & 8 & 405 & 18 & 2 & 0 & 433 & 8 & 723 & 26 & 1 & 14 & 772 \\
\hline & $1970-79$ & 6 & 310 & 23 & 1 & 2 & 342 & 4 & 533 & 50 & 0 & 18 & 605 \\
\hline & $1980-86$ & 1 & 164 & 10 & 0 & 6 & 181 & 0 & 205 & 10 & 0 & 18 & 233 \\
\hline \multirow{6}{*}{ 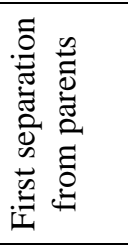 } & 1930-39 & 3 & 130 & 40 & 20 & 0 & 193 & 18 & 458 & 74 & 39 & 0 & 589 \\
\hline & $1940-49$ & 8 & 156 & 36 & 16 & 0 & 216 & 5 & 442 & 71 & 35 & 1 & 554 \\
\hline & $1950-59$ & 3 & 288 & 76 & 22 & 4 & 393 & 10 & 757 & 112 & 47 & 14 & 940 \\
\hline & $1960-69$ & 4 & 324 & 75 & 14 & 16 & 433 & 10 & 642 & 89 & 17 & 14 & 772 \\
\hline & $1970-79$ & 2 & 266 & 53 & 3 & 18 & 342 & 13 & 490 & 66 & 4 & 32 & 605 \\
\hline & 1980-86 & 5 & 112 & 19 & 0 & 45 & 181 & 5 & 181 & 10 & 0 & 37 & 233 \\
\hline \multirow{6}{*}{ 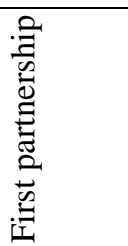 } & 1930-39 & 0 & 29 & 12 & 22 & 130 & 193 & 0 & 95 & 43 & 61 & 390 & 589 \\
\hline & $1940-49$ & 0 & 29 & 17 & 23 & 147 & 216 & 0 & 107 & 46 & 54 & 347 & 554 \\
\hline & $1950-59$ & 2 & 62 & 41 & 42 & 246 & 393 & 3 & 187 & 121 & 112 & 517 & 940 \\
\hline & $1960-69$ & 0 & 99 & 69 & 30 & 235 & 433 & 0 & 212 & 90 & 68 & 402 & 772 \\
\hline & $1970-79$ & 1 & 126 & 72 & 3 & 140 & 342 & 2 & 263 & 92 & 6 & 242 & 605 \\
\hline & $1980-86$ & 0 & 111 & 14 & 0 & 56 & 181 & 0 & 149 & 16 & 0 & 68 & 233 \\
\hline \multirow{6}{*}{ 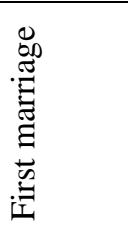 } & 1930-39 & 0 & 93 & 82 & 9 & 9 & 193 & 0 & 387 & 105 & 17 & 80 & 589 \\
\hline & $1940-49$ & 0 & 137 & 64 & 6 & 9 & 216 & 0 & 391 & 85 & 12 & 66 & 554 \\
\hline & $1950-59$ & 0 & 261 & 91 & 16 & 25 & 393 & 1 & 686 & 140 & 20 & 93 & 940 \\
\hline & $1960-69$ & 0 & 261 & 115 & 12 & 45 & 433 & 0 & 593 & 86 & 8 & 85 & 772 \\
\hline & $1970-79$ & 0 & 191 & 68 & 3 & 80 & 342 & 0 & 460 & 45 & 4 & 96 & 605 \\
\hline & $1980-86$ & 0 & 41 & 14 & 0 & 126 & 181 & 0 & 106 & 12 & 0 & 115 & 233 \\
\hline \multirow{6}{*}{ 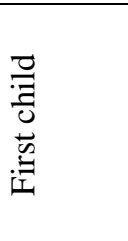 } & 1930-39 & 0 & 62 & 105 & 11 & 15 & 193 & 0 & 370 & 164 & 11 & 44 & 589 \\
\hline & $1940-49$ & 0 & 110 & 96 & 2 & 8 & 216 & 0 & 366 & 134 & 12 & 42 & 554 \\
\hline & $1950-59$ & 0 & 202 & 141 & 14 & 36 & 393 & 0 & 633 & 229 & 26 & 52 & 940 \\
\hline & $1960-69$ & 0 & 218 & 160 & 16 & 39 & 433 & 0 & 573 & 146 & 7 & 46 & 772 \\
\hline & $1970-79$ & 0 & 152 & 120 & 4 & 66 & 342 & 0 & 463 & 94 & 3 & 45 & 605 \\
\hline & $1980-86$ & 0 & 36 & 38 & 0 & 107 & 181 & 0 & 140 & 22 & 0 & 71 & 233 \\
\hline
\end{tabular}

Source: Made by the author based on the panel data of the Russian part of GGS for 2011. 
Appendix 2. Median ages of the onset of starting events

\begin{tabular}{|c|c|c|c|c|c|c|c|}
\hline Generation & $\begin{array}{l}\text { Graduation } \\
\text { from school }\end{array}$ & $\begin{array}{c}\text { Professional } \\
\text { education }\end{array}$ & First job & $\begin{array}{c}\text { First } \\
\text { separation } \\
\text { from parents }\end{array}$ & $\begin{array}{c}\text { First } \\
\text { partnership }\end{array}$ & $\begin{array}{c}\text { First } \\
\text { marriage }\end{array}$ & First child \\
\hline \multicolumn{8}{|c|}{ Men } \\
\hline 1930-1939 & 16 & 25 & 17 & 22 & 26 & 24 & 26 \\
\hline 1940-1949 & 17 & 24 & 18 & 21 & 27 & 23 & 24 \\
\hline $1950-1959$ & 17 & 21 & 18 & 21 & 25 & 23 & 24 \\
\hline 1960-1969 & 17 & 21 & 20 & 20 & 25 & 23 & 24 \\
\hline $1970-1979$ & 16 & 20 & 20 & 20 & 23 & 23 & 24 \\
\hline 1980-1986 & 17 & 21 & 20 & 19 & 20 & 22 & 25 \\
\hline Всего & 17 & 21 & 19 & 20 & 23 & 23 & 24 \\
\hline \multicolumn{8}{|c|}{ Women } \\
\hline 1930-1939 & 16 & 23 & 18 & 20 & 25 & 22 & 23 \\
\hline 1940-1949 & 17 & 23 & 18 & 20 & 24 & 21 & 22 \\
\hline $1950-1959$ & 17 & 21 & 18 & 19 & 26 & 21 & 22 \\
\hline 1960-1969 & 17 & 20 & 18 & 19 & 23 & 20 & 21 \\
\hline 1970-1979 & 17 & 21 & 19 & 19 & 20 & 20 & 21 \\
\hline 1980-1986 & 17 & 21 & 20 & 19 & 19 & 20 & 21 \\
\hline Всего & 17 & 21 & 18 & 19 & 23 & 21 & 22 \\
\hline \multicolumn{8}{|c|}{ All } \\
\hline 1930-1939 & 16 & 24 & 18 & 20 & 25 & 23 & 24 \\
\hline 1940-1949 & 17 & 23 & 18 & 20 & 25 & 22 & 23 \\
\hline 1950-1959 & 17 & 21 & 18 & 20 & 26 & 22 & 23 \\
\hline $1960-1969$ & 17 & 20 & 19 & 19 & 23 & 21 & 22 \\
\hline 1970-1979 & 16 & 21 & 19 & 19 & 22 & 21 & 22 \\
\hline 1980-1986 & 17 & 21 & 20 & 19 & 20 & 21 & 22 \\
\hline Total & 17 & 21 & 19 & 20 & 23 & 21 & 23 \\
\hline
\end{tabular}

Source: Made by the author based on the panel data of the Russian part of GGS for 2011.

Appendix 3. Median ages of the onset of the first and last events of the transition to adulthood, as well as the median duration of transition to adulthood

\begin{tabular}{l|c|c|c|c}
\hline Gender & Generations & $\begin{array}{c}\text { Median age of the } \\
\text { onset of a first event }\end{array}$ & $\begin{array}{c}\text { Median age of the } \\
\text { onset of a last event }\end{array}$ & $\begin{array}{c}\text { Median duration of } \\
\text { transition to } \\
\text { adulthood }\end{array}$ \\
\hline \multirow{3}{*}{ Men } & $1930-39$ & 17 & 30 & 12.8 \\
& $1940-49$ & 17 & 27 & 9.7 \\
& $1950-59$ & 17 & 27 & 9.3 \\
& $1960-69$ & 18 & 26 & 8.3 \\
& $1970-79$ & 18 & 26 & 5.7 \\
Women & $1980-86$ & 18 & 24 & 8.3 \\
& $1930-39$ & 18 & 26 & 7.8 \\
& $1940-49$ & 17 & 26 & 7.9 \\
& $1950-59$ & 17 & 25 & 6.1 \\
& $1960-69$ & 17 & 24 & 6.5 \\
\end{tabular}

Source: Made by the author based on the panel data of the Russian part of GGS for 2011. 
Appendix 4. The number of starting events and the "speed" of transition to adulthood in the context of generations

\begin{tabular}{l|c|c|c|c|c|c}
\hline \multirow{2}{*}{ Generations } & \multicolumn{3}{|c|}{$\begin{array}{c}\text { The number of starting events in the context of } \\
\text { generations }\end{array}$} & \multicolumn{3}{c}{$\begin{array}{c}\text { "Speed" of transition to adulthood in the } \\
\text { context of generations }\end{array}$} \\
\cline { 2 - 7 } & average & $\begin{array}{c}\text { Number of } \\
\text { respondents }\end{array}$ & $\begin{array}{c}\text { Standard } \\
\text { deviation }\end{array}$ & average & $\begin{array}{c}\text { Number of } \\
\text { respondents }\end{array}$ & $\begin{array}{c}\text { Standard } \\
\text { deviation }\end{array}$ \\
\hline $1930-39$ & 4.46 & 782 & 0.685 & 0.69 & 695 & 0.792 \\
$1940-49$ & 4.57 & 770 & 0.632 & 0.80 & 673 & 1.223 \\
$1950-59$ & 4.66 & 1333 & 0.601 & 0.81 & 1105 & 1.069 \\
$1960-69$ & 4.63 & 1205 & 0.675 & 0.95 & 999 & 1.064 \\
$1970-79$ & 4.51 & 947 & 0.818 & 1.06 & 770 & 1.277 \\
$1980-86$ & 3.60 & 414 & 1.161 & 1.23 & 276 & 2.391 \\
Total & 4.50 & 5451 & 0.776 & 0.89 & 4518 & 1.223 \\
\hline
\end{tabular}

Source: Made by the author based on the panel data of the Russian part of GGS for 2011. 